\title{
Ligninolytic enzymes: a biotechnological alternative for bioethanol production
}

\author{
Jersson Plácido* and Sergio Capareda
}

\begin{abstract}
Ligninolytic fungi and enzymes (i.e., laccase, manganese peroxidase, and lignin peroxidase) have been applied recently in the production of second-generation biofuels. This review contains the analysis of ligninolytic enzymes and their applications in second-generation biofuels. In here, each of the ligninolytic enzymes was described analyzing their structures, catalysis, and reaction mechanism. Additionally, delignification and detoxification, the two most important applications of ligninolytic enzymes, were reviewed and analyzed. The analysis includes an evaluation of the biochemical process, feedstocks, and the ethanol production. This review describes the current situation of the ligninolytic enzymes technology and its future applications in bioethanol industry.
\end{abstract}

Keywords: Ligninolytic fungi; Bioethanol; Laccases; Manganese peroxidase; Lignin peroxidase; Detoxification; Delignification

\section{Review}

\section{Introduction}

The United States regulation requires 36 billion gallons of biofuels, and 21 billion should be produced from lignocellulosic material or other new advanced fuels by 2020 [1]. Lignocellulose, the most abundant source of organic material in the world, is a polysaccharide combination of cellulose, hemicellulose, and lignin [2]. Bioethanol is one of the most essential biofuels produced from lignocellulosic material. In general, bioethanol production from lignocellulosic material includes three principal steps: 1) pretreatment, 2) saccharification, and 3) fermentation. The pretreatment process modifies the lignocellulose structure by removing the lignin and altering the cellulose and hemicellulose structure [3]. Saccharification is the enzymatic transformation of cellulose and hemicellulose into monosaccharides as glucose and xylose. Whereas, fermentation is the transformation of these monosaccharides into ethanol. The current pretreatment methodologies utilize energy-intensive processes (high pressures and temperatures) and harsh chemical compounds $\left(\mathrm{NaOH}, \mathrm{H}_{2} \mathrm{SO}_{4}\right)$. This combination generates undesirable compounds and process inefficiencies. To overcome these issues, biomass

\footnotetext{
* Correspondence: plac324@tamu.edu

Department of Biological and Agricultural Engineering, Texas A\&M University, 201 Scoates hall, 2117 TAMU, College Station, TX 77843, USA
}

pretreatment has explored more sustainable technologies such ligninolytic enzymes.

In nature, different organisms degrade lignin; however, the most effective ones are the fungi belonging to the white rot fungi class [4]. These microorganisms possess an enzymatic system to effectively degrade lignin. This system contains three principal enzymes laccase, manganese peroxidase (MnP), and lignin peroxidase (LiP) [5]. These microorganisms have been used to delignify different substrates such paper, animal feed, and biofuels [3,6-8]. In biofuel production, the ligninolytic enzymes have two principal purposes, delignification and detoxification. Delignification methods apply ligninolytic fungus and their enzymes to reduce the lignin content in several feedstocks [3,5-8]. Detoxification utilizes the ligninolytic enzymes to reduce the toxic compounds present in the biomass hydrolysates after chemical or physicochemical pretreatments [9-14].

The aim of this review is to describe the relevant aspects of the ligninolytic enzymes laccase, MnP, and LiP and to analyze the present and future application of this technology in the production of biofuels.

\section{Ligninolytic enzymes}

Laccases

Laccases (E.C. 1.10.3.2) also known as benzenediol: oxygen oxidoreductase or $\mathrm{p}$-diphenol oxidase belong to the

\section{实}


oxidoreductase class. Yoshida, at the end of the nineteenth century, was the first to extract laccases from exudates of the Japanese tree Rhus vernicifera. Laccases are widely distributed in microorganisms, insects, and plants, showing a specific function in each of them. From this group, white rot fungi are the most studied laccases. These fungi use their enzymes to break the plant's lignocellulosic wall and obtain the host's nutrients. These fungal enzymes degrade the complex polyphenol structure that constitutes lignin, the principal recalcitrant component in the lignocellulosic wall. Besides their catalytic characteristics, these enzymes are attractive for biotechnological process, because they are extracellular and inducible, do not need a cofactor, and have low specificity. Laccase production is induced and increased by the addition of molecules as copper, dyes, or other recalcitrant compounds [15]. Laccase employs oxygen as an oxidizing agent and cofactor instead of other expensive cofactors such as pantothenic acid, thiamine, or biotin [16].

Laccases have low substrate specificity; this characteristic allows the degradation of several compounds with a phenolic structure [17]. Therefore, laccases have been employed in several areas such as bioremediation of aromatic recalcitrant compounds [18], treatment of effluents polluted with lignin [19], chemical synthesis [20,21], degradation of a wide number of textile dyes [22-25], and biomass pretreatment for biofuel production [26-28].

Laccase structure and catalytic mechanism Laccases have a primary structure of approximately 500 amino acid residues organized in three consecutive domains, with a Greek key $\beta$ barrel topology. The three domains are distributed in a first domain with 150 initial amino acids, a second domain between the 150 and 300 residue, and a third domain from the 300 to 500 amino acid. The structure is stabilized by two disulfide bridges localized between domains I and II and between domains I and III $[16,29,30]$. However, some laccases present three disulfide bridges. Melanocarpus albomyces has disulfide bridges inside domain I, another between domain I and domain III, and the last one between domain II and III [31].

Laccase belongs to multicopper oxidases (MCOs) and blue multicopper oxidases [21]. Laccases have four copper $(\mathrm{Cu})$ molecules in their active site which participate in oxygen reduction and water production (Figure 1) [32]. The laccases' four copper atoms are disseminated in three types of cores or places: type $1 \mathrm{Cu}$ (T1), type 2 $\mathrm{Cu}$ (T2), and type $3 \mathrm{Cu}$ (T3). These cores are in two metallic active sites: the mononuclear location $\mathrm{T} 1$ and the trinuclear location T2/T3 [16,21,29,30]. Type $1 \mathrm{Cu}$ (T1) or blue $\mathrm{Cu}$ is a paramagnetic copper with a strong absorption at $600 \mathrm{~nm}$ (blue coloration). This signal is generated by the covalent union between $\mathrm{Cu}-\mathrm{Cys}$ in the mononuclear location $[16,33]$. In addition, $\mathrm{T} 1$ has the

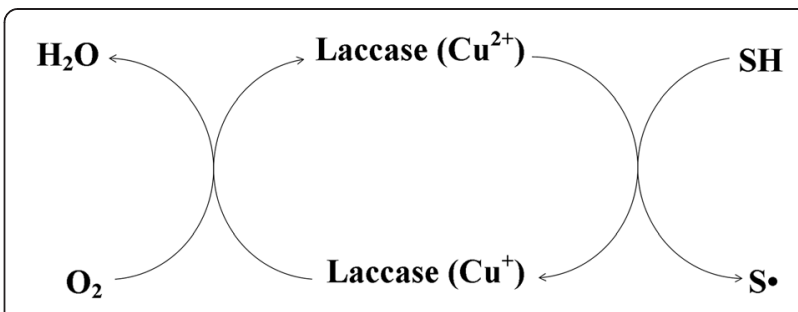

Figure 1 General diagram of laccase redox mechanism (SH reduced substrate, $\mathrm{S} \cdot$ oxidized substrate).

highest redox potential in the enzyme and participates in the enzymatic catalysis by oxidizing the substrate [16]. Laccase's oxidative power is affected by the amino acids surrounding T1 [16]. Similar to T1, T2 is a paramagnetic cooper; however, it lacks absorption in the visible region of the spectrum. This $\mathrm{Cu}$ exhibits a strong absorption under electron paramagnetic resonance (EPR); technique employed to identify this spot [16]. In addition, the T2/T3 core participates in the inhibition of the enzymatic activity by its interaction with anions such as fluoride or cyanide [34]. On the other hand, $\mathrm{T} 3 \mathrm{Cu}$ is a binuclear core formed by a $\mathrm{Cu}$ (II) dimer. This site presents absorption at $330 \mathrm{~nm}$ and a lack of EPR signal. Type 3 coppers are diamagnetic and have a $\mathrm{Cu}-\mathrm{Cu}$ union which participates in the compound oxidation as an electron acceptor.

In laccases, the different types of coppers have variations associated with the coordination between them and the amino acids in the active site. T1 $\mathrm{Cu}$ exhibits a different triangular planar coordination similar to other MCOs. Laccases display two histidines (His) and one cysteine (Cys) as equatorial ligands. Meanwhile, the other MCOs have an additional axial ligand with a methionine. In contrast, laccases did not have this axial extra bond, they have a leucine (Leu) or a phenylalanine (Phe) substituting methionine [16,29-31]. On the other hand, T2 $\mathrm{Cu}$ exhibits coordination with two His and a water molecule; whereas, T3 $\mathrm{Cu}$ interacts with a water molecule and six His. In T3 $\mathrm{Cu}$, the two $\mathrm{Cu}$ molecules share the water molecule and split the six His in two groups of three $[16,29,30]$. The two T3 $\mathrm{Cu}$ interact with the oxygen atom; however, the interaction between water and the two $\mathrm{Cu}$ at the same time only happens when the enzyme is in its oxidized form [16,29-31,33].

Laccase crystalline structures evidenced that $\mathrm{T} 2 \mathrm{Cu}$ (EPR active) could be any of the three $\mathrm{Cu}$ in the trinuclear site. In this site, two of the $\mathrm{Cu}$ reduce and become silent to EPR. Meanwhile, the other one remains active to EPR [35]. This interchange between $\mathrm{T} 2 \mathrm{Cu}$ and one of T3 coppers could be related to the reduction mechanism of the two oxygen molecules (cofactor), mechanism which is not clear for blue multicopper oxidases [35].

The enzymes' redox potential oscillates between 300 and $800 \mathrm{mV}$; these fluctuations depend on different factors 
such $\mathrm{Cu}$ ligands, distance among $\mathrm{Cu}$, and the second sphere of amino acids in the active site. The last factor is associated with the degradation of recalcitrant compounds as lignin or industrial dyes [16].

Another structural characteristic in laccases is the presence of ligands: monosaccharides (mannose, $\mathrm{N}$-acetyl glucosamine), ions like $\mathrm{Ca}^{2+}$, and organic molecules like glycerol $[16,29-31,35]$. The presence of these ligands produce significant differences between laccases, an example of that is the glycosylations exhibited in the isoenzymes from Trametes versicolor [30].

\section{Heme-peroxidases}

After laccases, lignin peroxidase (LiP) and manganese peroxidase $(\mathrm{MnP})$ are the most significant ligninolytic enzymes. These enzymes belong to the heme-proteins because they have the protoporphyrin IX as a prosthetic group. Similar to other heme-peroxidases such cytochrome c peroxidase and horseradish peroxidase, the catalytic cycle of LiP and MnP have three reactions [32,36-39].

Hydrogen peroxide causes the enzyme oxidation to produce the compound I and water:

Reduced peroxidase $+\mathrm{H}_{2} \mathrm{O}_{2} \rightarrow$ Compound $\mathrm{I}+\mathrm{H}_{2} \mathrm{O}$

The modified enzyme (compound I) catalyzes the production of a free radical $\left(S_{\bullet}\right)$ and a second modified form of the enzyme (compound II) by an electron transfer from the substrate ( $\mathrm{SH}$ : reduced substrate):

Compound I $+\mathrm{SH} \rightarrow$ Compound II $+\mathrm{S}$ •

Finally, compound II reacts with a second substrate molecule to produce another free radical and water; meanwhile, the enzyme reduces to its original form.

Compound II $+\mathrm{SH} \rightarrow$ Reduced peroxidase $+\mathrm{S} \bullet+\mathrm{H}_{2} \mathrm{O}$

Lignin peroxidase (LiP) LiPs (E.C. 1.11.1.14) were originally discovered in nitrogen- and carbon-limited cultures of Phanerochaete chrysosporium [32]. LiP possess high redox potential (700 to $1,400 \mathrm{mV}$ ), low optimum $\mathrm{pH} 3$ to 4.5, and the ability to catalyze the degradation of a wide number of aromatic structures such veratryl alcohol (3,4-dimethoxybenzyl) and methoxybenzenes [32,36,38]. LiP oxidizes aromatic rings moderately activated by electron donating substitutes; in contrast, common peroxidases participate in the catalysis of aromatic substrates highly activated (ammine, hydroxyl, etc.). An explanation for this type of catalysis is the production of veratryl alcohol radicals. These radicals have higher redox potential than LiP's compounds I and II and can participate in the degradation of compounds with high redox potential [40].

LiPs are monomeric glycosylated enzymes of $40 \mathrm{kDa}$, with 343 amino acids residues, 370 water molecules, a heme group, four carbohydrates, and two calcium ions [39]. Their secondary structure is principally helicoidal. It contains eight major helixes, eight minor helixes, and two anti-parallel beta sheets. LiPs contain two domains at both sides of the heminic group. This group is inlaid in the protein but accessible to solvents via two small channels [39]. The heminic cavity includes 40 residues, and it bonds to the protein via hydrogen bridges. Additionally, the heminic iron (Fe) coordinates with a His and a molecule of water. This His is associated with the high redox potential of LiP. The enzyme's redox potential rises when the His has a reduced imidazol character [39]. In addition, a greater distance between the His and the heminic group increases the redox potential of the enzyme. This increment in the redox potential is a response to the electronic deficiency in the Fe of the porphyrin ring. In fact, this distance causes most differences among enzymes with similar porphyrin cores [39,41].

Another characteristic related with LiP's high redox potential is the invariant presence of a tryptophan residue (Trp171) in the enzymes' surface. Trp171 seems to facilitate electronic transference to the enzyme from substrates that cannot access into the heminic oxidative group [41]. Additionally, Trp171 participates with the catalysis of veratryl alcohol, a metabolite produced by some ligninolytic fungi. Veratryl alcohol participates in the oxidation of different aromatic molecules. Some researchers conceptualized that this alcohol protects the enzyme from the action of $\mathrm{H}_{2} \mathrm{O}_{2}$ and participate as a redox mediator between the enzyme and substrates which cannot get inside the heminic center [38,39].

Manganese peroxidase (MnP) Kuwahara in 1984 found the first MnP (E.C. 1.11.1.13) in batch cultures of Phanerochaete chrysosporium [32]. They are glycoproteins with a molecular weight between 38 and $62.5 \mathrm{kDa}$ [42], approximately 350 amino acid residues, and a $43 \%$ of identity with LiP sequence. MnP structure has two domains with the heminic group in the middle, ten major helixes, a minor helix, and five disulfide bridges. One of those bridges participates in the manganese $(\mathrm{Mn})$ bonding site. This site is a characteristic that distinguishes $\mathrm{MnP}$ from other peroxidases [37].

The enzyme's catalytic cycle starts with the transference of two electrons from the heminic group to $\mathrm{H}_{2} \mathrm{O}_{2}$; it produces compound I and water. After that, compound I catalyzes the oxidation of one substrate molecule with the production of a free radical and compound II. Compound II oxidizes $\mathrm{Mn}^{2+}$ to produce $\mathrm{Mn}^{3+}$, the cation responsible to oxidize aromatic compounds. It is important to keep in mind that compound II demands $\mathrm{Mn}^{2+}$ presence for its reaction; in contrast, compound I can oxidize $\mathrm{Mn}^{2+}$ or the substrate. After $\mathrm{Mn}^{3+}$ is stabilized by organic acids, it reacts non-specifically with organic molecules by removing an electron and a proton from the substrates [42]. $\mathrm{Mn}^{3+}$ is a small size compound with high redox potential, which diffuses easily in the lignified cell wall. Therefore, $\mathrm{Mn}^{3+}$ starts the attack inside 
the plant cell wall which facilitates the penetration and action of the other enzymes $[38,41]$.

\section{Sources of ligninolytic enzymes}

The ligninolytic enzymes are a ubiquitous group of enzymes found in different types of organisms as plants, bacteria, insects, and fungi. In plants, laccases are the most documented ligninolytic enzyme; these are extracellular glycoproteins composed by a monomeric protein with a sugar component. Laccases have been found in different types of plants: the Japanese lacquer tree, mango, mung bean, peach, tobacco, zea mays, etc. [43]. In plants, laccases realize different kind of functions such as lignin synthesis [43], iron oxidation from $\mathrm{Fe}(\mathrm{II})$ to $\mathrm{Fe}(\mathrm{III})$ [44], and regeneration of injured tissue [43]. In plants, lignin synthesis is laccases' most significant function. In these organisms, they catalyze the monolignol dimerization, the basic molecules of lignin polymers and oligomers [43].

In bacteria, lignin breakdown is exhibited by three groups: actinomycetes, $\alpha$-proteobacteria, and $\gamma$-proteobacteria [45]. These three groups of bacteria were described in insects degrading wood microflora. These types of bacteria showed delignification in both in vitro and in vivo analyses [45]. Streptomyces viridosporus, actinomycetes species, and Thermobifida fusca exhibited LiP activities [45-47]. In contrast, Azospirillum lipoferum, Thermus thermophilus, Marinomonas mediterranea, Bacillus subtilis, and Streptomyces cyaneus showed laccase activity [48-51]. Bacterial laccases are intracellular enzymes with a monomeric, multimeric, or homotrimeric structure without carbohydrate moiety [43]. In nature, bacteria use laccases in spore protection and pigmentation. This type of enzymes exhibited resistance to high $\mathrm{pH}$ and temperatures $[43,45,52]$.

In insects, the delignification process is done by ligninolytic enzymes produced by the insects or by the insects' microflora. The ligninolytic enzymes have been identified in different insects and different parts of them. An example of that are Nephotettix cincticeps (salivary glands) [53], Manduca sexta (Malpighian tubules, midgut, fat body, and epidermis) [54], Reticulitermes flavipes (gut) [55], and Tribolium castaneum (cuticles) [56]. The principal functions of insect's ligninolytic enzymes are cuticle sclerotization and pigmentation, toxic compound oxidation, and polymerization reactions $[43,53]$.

The fungal ligninolytic enzymes are the most well-known enzymes, and they occur in ascomycetes, basidiomycetes, and deuteromycetes [57]. Inside these groups are several fungal species; however, the most studied fungi are: Trametes versicolor, Phanerochaete chrysosporium, Pleurotus ostreatus, Dichomitus squalens, Lentinula edodes, Irpex lacteus, and Cerrena maxima [32,58]. The principal functions of fungal ligninolytic enzymes are lignin degradation, spore and fruiting body formation, and degradation of plant's toxic compounds $[32,57]$.

\section{Biofuel applications}

In the last years, ligninolytic fungi and their enzymes have appeared as a new alternative for pretreatment processes. This technology has been useful principally in two processes, delignification and detoxification. In delignification, ligninolytic fungi or their enzymes have been used to reduce the lignin content in different types of feedstock $[3,4,59]$. Whereas, in detoxification, ligninolytic enzymes have been used in the removal of chemical compounds from sugar hydrolysates after traditional pretreatments.

\section{Delignification}

In delignification process, ligninolytic enzymes have been applied in four different methods: 1) fungal delignification, 2) enzymatic delignification, 3) laccase-mediator system (LMS), and 4) integrated fungal fermentation (IFF). Table 1 resumes the application of these four delignification technologies. Fungal delignification utilizes the complete ligninolytic microorganisms for biomass delignification. In those cases, the microorganisms grow with the target biomass in a submerged culture $[8,60]$ or a solid state fermentation $[3,7]$. Both cultivations achieved good delignification percentages; however, these were not always related with high glucose yields. The work of Salvachúa et al. (2011) is an example of that; in that case, the fungi with higher glucose yield were different from the ones with the highest delignification percentage. However, the lack of relation between high glucose yield and high delignification percentage occurs in different pretreatments and not only in microbial delignification. In fact, the principal issue with fungal pretreatment is the large duration of the process compared with the other pretreatment technologies [5]. The length of time used by the microorganisms to obtain high delignification percentages is not less than 13 days and can be up to 40 or 50 days $[4,8]$ However, this period will depend on the strain used. The effectiveness of microbial delignification has been improved by adding an alkali treatment previous the fungal pretreatment. The alkali pretreatment benefits were the reduction of the process duration and the increment in the glucose and ethanol yield [61,62].

Enzymatic delignification is the application of enzymatic extracts and purified or semi-purified ligninolytic enzymes to realize the lignin degradation. Enzymatic delignification employs commercial or native ligninolytic enzymes [63]. Laccase is the most utilized enzyme followed by $\mathrm{MnP}$ and LiP; nevertheless, mixtures of two or three ligninolytic enzymes have been used for some delignification pretreatments. In those cases, the synergetic relationship between 
Table 1 Delignification methods using ligninolytic fungi and ligninolytic enzymes

\begin{tabular}{|c|c|c|c|c|c|c|c|c|}
\hline Feedstock & Fungal strain & Type of process & Mediator & Delignification \% & Glucose yield & Ethanol yield & Process duration & Ref. \\
\hline Wood pulp & Trametes villosa & $\begin{array}{l}\text { Enzymatic } \\
\text { Laccase }\end{array}$ & $\begin{array}{l}\text { HBT } \\
\text { HPA }\end{array}$ & $\begin{array}{l}50 \% \\
39 \%\end{array}$ & - & - & $15 \mathrm{~h}$ & [81] \\
\hline Wood pulp & Aspergillus fumigatus & $\begin{array}{l}\text { Enzymatic } \\
\text { Laccase }\end{array}$ & HBT & $14 \%$ & - & - & $2 \mathrm{~h}$ & [59] \\
\hline Hardwood chips & Trametes versicolor & $\begin{array}{l}\text { Enzymatic } \\
\text { Laccase }\end{array}$ & VA & $54.2 \%$ & - & - & $2 \mathrm{~h}$ & [82] \\
\hline Sugarcane bagasse & Ceriporiopsis subvermispora & $\begin{array}{l}\text { Fungal } \\
\text { MnP, } \\
\text { LiP, } \\
\text { Laccase }\end{array}$ & - & $20 \%$ & - & - & $30 d$ & [64] \\
\hline Eucalyptus globulus & Myceliophthora thermophila & $\begin{array}{l}\text { Enzymatic } \\
\text { Laccase }\end{array}$ & MS & $>25 \%$ & - & - & $12 \mathrm{~h}$ & [19] \\
\hline Paper pulp & Pycnoporus cinnabarinus & $\begin{array}{l}\text { Enzymatic } \\
\text { Laccase }\end{array}$ & $\begin{array}{l}\text { AC } \\
\text { SA } \\
\text { CA } \\
\text { HBT }\end{array}$ & $\begin{array}{l}21 \% \\
25 \% \\
-9 \% \\
40 \%\end{array}$ & - & - & $4-24 \mathrm{~h}$ & [69] \\
\hline $\begin{array}{l}\text { Corn stover } \\
\text { Switchgrass }\end{array}$ & Ceriporiopsis subvermispora & $\begin{array}{l}\text { Fungal } \\
\text { Laccase }\end{array}$ & - & $\begin{array}{l}>25 \% \\
>25 \%\end{array}$ & $\begin{array}{l}56 \% \\
37 \%\end{array}$ & - & $18 d$ & [4] \\
\hline Ricinus communis & - & $\begin{array}{l}\text { Enzymatic } \\
\text { Laccase }\end{array}$ & - & $85.69 \%$ & $288.83 \mathrm{mg} / \mathrm{g}$ & - & $4 \mathrm{~h}$ & [83] \\
\hline Eucalyptus globulus & Pycnoporus cinnabarinus & $\begin{array}{l}\text { Enzymatic } \\
\text { Laccase }\end{array}$ & HBT & $27 \%$ & - & - & $2-4 h$ & [84] \\
\hline Wheat straw & $\begin{array}{l}\text { Isolate Euc, } \\
\text { Irpex lacteus }\end{array}$ & $\begin{array}{l}\text { Fungal } \\
\text { Laccase }\end{array}$ & - & $\begin{array}{l}35 \% \\
35 \%\end{array}$ & $\begin{array}{l}70 \% \\
70 \%\end{array}$ & - & $15-46 d$ & [2] \\
\hline Wheat straw & $\begin{array}{l}\text { Ceriporiopsis subvermispora } \\
\text { Irpex lacteus }\end{array}$ & $\begin{array}{l}\text { Fungal } \\
\text { MnP, } \\
\text { LiP, } \\
\text { Laccase }\end{array}$ & - & $\begin{array}{l}34 \% \\
39 \%\end{array}$ & $\begin{array}{l}69 \% \\
66 \%\end{array}$ & $90 \%$ & $21 d$ & [3] \\
\hline Corn stover & Ceriporiopsis subvermisporal & $\begin{array}{l}\text { Fungal } \\
\text { MnP } \\
\text { Laccase }\end{array}$ & - & $39.2 \%$ & $66.9 \%$ & - & $42 d$ & [7] \\
\hline $\begin{array}{l}\text { Corn stover (cs) } \\
\text { Wheat straw (ws) }\end{array}$ & Pycnoporus sanguineus H275 & $\begin{array}{l}\text { Fungal } \\
\text { Laccase }\end{array}$ & $\begin{array}{l}- \\
- \\
V A\end{array}$ & $\begin{array}{l}27 \% \text { (cs) } \\
25 \% \text { (ws) } \\
71 \% \text { (cs) } \\
72 \% \text { (ws) }\end{array}$ & - & - & $21 d$ & [8] \\
\hline $\begin{array}{l}\text { Elephant grass (eg) } \\
\text { Eucalypt wood (ew) }\end{array}$ & Trametes villosa & LMS & HBT & $\begin{array}{l}36 \%(\mathrm{eg}) \\
58 \%(\mathrm{ew})\end{array}$ & $\begin{array}{l}70.7 \%(\mathrm{eg}) \\
57.8(\mathrm{ew})\end{array}$ & $\begin{array}{l}16.2 \%(\mathrm{eg}) \\
12.3 \%(\mathrm{ew})\end{array}$ & $24 \mathrm{~h}$ & [72] \\
\hline Corn stover & Trametes versicolor & LMS & HBT & - & $31.7 \%$ & - & $48 \mathrm{~h}$ & [70] \\
\hline Wheat straw & Sclerotium sp. & LMS & ABTS & - & $82.29 \%$ & - & $48 \mathrm{~h}$ & [71] \\
\hline Cotton gin trash & Trametes versicolor & LMS & PrimaGreen ${ }^{\oplus}$ & $15 \%$ & $23 \%$ & $31.6 \%$ & $96 \mathrm{~h}$ & [27] \\
\hline Cotton gin trash & Trametes versicolor & LMS & PrimaGreen ${ }^{\oplus}$ & $27 \%$ & $41 \%$ & $64 \%$ & $96 \mathrm{~h}$ & [28] \\
\hline
\end{tabular}


Table 1 Delignification methods using ligninolytic fungi and ligninolytic enzymes (Continued)

\begin{tabular}{|c|c|c|c|c|c|c|c|c|}
\hline Sugarcane bagasse & Pleurotus ostreatus IBL-02 & $\begin{array}{l}\text { Enzymatic } \\
\text { MnP, } \\
\text { LiP, } \\
\text { Laccase }\end{array}$ & - & $33.6 \%$ & $72.9 \%$ & $16.3 \mathrm{~g} / \mathrm{L}$ & $48 \mathrm{~h}$ & {$[67]$} \\
\hline Wheat straw & $\begin{array}{l}\text { T. versicolor } \\
\text { I. lacteus }\end{array}$ & $\begin{array}{l}\text { Fungal } \\
\text { MnP } \\
\text { LiP } \\
\text { Laccase }\end{array}$ & - & - & $\begin{array}{l}68.33 \% \\
56.26 \%\end{array}$ & - & $21 d$ & {$[85]$} \\
\hline Sugarcane bagasse & Phlebia sp MG-60 & IFF & & $30 \%$ & - & $45 \%$ & 4 weeks & {$[86]$} \\
\hline Sugarcane bagasse & $\begin{array}{l}\text { Phanerochaete chrysosporium } \\
\text { Lentinula edode } \\
\text { Pleurotus ostreatus }\end{array}$ & $\begin{array}{l}\text { Fungal } \\
\mathrm{MnP}\end{array}$ & - & $64 \%$ & - & - & 12 weeks & {$[87]$} \\
\hline $\begin{array}{l}\text { Oil palm empty fruit } \\
\text { bunches }\end{array}$ & Pleurotus floridanus & Fungal & & $5 \%$ & $15.4 \%$ & $27.9 \%$ & 4 weeks & {$[88]$} \\
\hline Corn stover & Coprinus comatus & IFF & & $66.5 \%$ & $82 \%$ & & $5-7 d$ & {$[76]$} \\
\hline Wheat straw & Irpex lacteus & $\begin{array}{l}\text { Fungal } \\
\text { MnP } \\
\text { Laccase }\end{array}$ & - & - & $84 \%$ & $74 \%$ & $14-21 d$ & {$[62]$} \\
\hline Corn stover & $\begin{array}{l}\text { Phanerochete chrysosporium } \\
\text { Coridus versicolor }\end{array}$ & $\begin{array}{l}\text { Enzymatic } \\
\text { MnP } \\
\text { Laccase }\end{array}$ & - & - & $323 \mathrm{mg} / \mathrm{g}$ & - & $24 \mathrm{~h}$ & {$[66]$} \\
\hline Bamboo culms & Punctularia sp. & Fungal & & - & $10 \%$ & - & 12 weeks & {$[89]$} \\
\hline Poplar wood & Trametes velutina & Fungal & - & & $43.6 \%$ & $22.2 \%$ & 8 weeks & {$[90]$} \\
\hline Sugarcane bagasse & Pleurotus florida & $\begin{array}{l}\text { Fungal } \\
\text { MnP } \\
\text { Laccase }\end{array}$ & - & $7.91 \%$ & $303.33 \mathrm{mg} / \mathrm{g}$ & - & $25 d$ & [91] \\
\hline Corn stover & Irpex lacteu & $\begin{array}{l}\text { Fungal } \\
\text { MnP }\end{array}$ & & $25.48 \%$ & $308.98 \mathrm{mg} / \mathrm{g}$ & $144.03 \mathrm{mg} / \mathrm{g}$ & $28 d$ & [92] \\
\hline $\begin{array}{l}\text { Sugarcane } \\
\text { Bagasse }\end{array}$ & Phlebia sp. MG-60 & IFF & - & - & - & $44 \%$ & 4 weeks & [75] \\
\hline $\begin{array}{l}\text { Hardwood kraft pulp, } \\
\text { Waste newspaper }\end{array}$ & Phlebia sp. MG-60 & IFF & - & - & - & $\begin{array}{l}71.8 \% \\
51.1 \%\end{array}$ & $68 \mathrm{~h}$ & [73] \\
\hline Sugarcane bagasse & Phlebia sp. MG-60 & IFF & - & - & - & $65.7 \%$ & $20 d$ & {$[61]$} \\
\hline Oak wood & Phlebia sp. MG-60 & IFF & - & - & - & $43.9 \%$ & $56 \mathrm{~d}$ & [74] \\
\hline
\end{tabular}

LMS: Laccase-Mediator System, IFF: Integrated fungal fermentation, HBT: 1-Hydroxybenzotriazole, HPA: N-Hydroxyphthalimide, MS: Methyl syringate, VA: Violuric acid, AC: Acetosyringone, SA: Syringaldehyde, CA: pcoumaric acid. 
the ligninolytic enzymes improved biomass delignification $[64,65]$. In wheat straw, ligninolytic enzymes generated a reduction in the cellulose conversion during the saccharification process. To avoid cellulases' inhibition, ligninolytic enzymes were deactivated before the saccharification process [66]. Similar to fungal delignification, alkali pretreatments have been used in enzymatic delignification as an initial pretreatment to facilitate the delignification process [66]. Enzymatic processes achieved similar delignification percentages than microbial pretreatment. However, enzymatic processes employ less amount of time (between 24 and $96 \mathrm{~h}$ ) to produce the same delignification achieved by fungal pretreatment [67]. Although this methodology reduces the delignification process duration, the current development of enzymatic delignification cannot compete with the conventional pretreatment technologies in terms of timespan and costs [5].

LMS utilize fungal laccases and redox mediators to achieve the delignification process. Redox mediators are chemical compounds, which act as electron carriers between the enzyme and the final substrate (Figure 2) [19]. Mediators' redox potential increases when the enzyme oxidizes them; after that, oxidized mediators react with the final substrate to recuperate the lost electrons. The increment in the redox potential allows the degradation of recalcitrant compounds such as lignin and different kinds of aromatic compounds that the enzyme by itself cannot break $[19,68]$. The mediator compounds most used are 1hydroxybenzotriazole (HBT), 2,2'-azino-bis(3-ethylbenzothiazoline-6-sulphonic acid) (ABTS), and some natural mediators as syringaldehyde or vanillin [69]. The principal applications of laccase-mediator system are bleaching and delignification in the paper industry. However, this system has been used for delignification of some biofuel feedstocks. In cotton gin trash, the delignification was performed by a commercial LMS from Genencor (Rochester, NY, USA). In that case, LMS was used after an ultrasonication and hot water pretreatments [27]. LMS was improved by the addition of alkali-ultrasonication process before the hot water and LMS pretreatment. Alkaliultrasonication duplicated the ethanol and cellulose yield compared with the previous method [28].

LMS pretreatment was utilized over corn stover by using HBT as mediator [70]. In there, a correlation between laccase loading and enzymatic digestibility was found. Additionally, they found the importance of corn

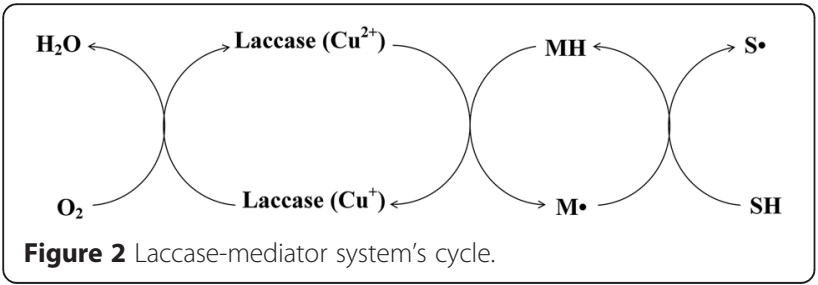

stover previous silage to increase LMS effectiveness [70]. In wheat straw, LMS pretreatment was used after the steam explosion pretreatment and was performed before and simultaneously with the enzymatic saccharification. The results in both processes were similar. Thus, LMS can participate in a semi-consolidate process for delignification and saccharification [71]. The application of LMS in elephant grass and eucalypt wood is the first report of LMS achieving significant delignification without a previous pretreatment. This improvement was achieved by using four steps of LMS pretreatment and $\mathrm{NaOH}$ washing [72]. LMS is less used in biofuels than the paper industry. This lack of applications is related with the small development of specific mediators for feedstock delignification.

Integrated fungal fermentation (IFF) is a consolidated process where a fungus or a group of fungi transform biomass into ethanol without the participation of other treatments or microorganisms [73]. Phlebia sp. MG-60 is a white rot fungus with the ability of selectively transforming lignin under solid state fermentation and produce ethanol from delignified biomasses under semi-aerobic submerged fermentation [74]. Phlebia sp. MG-60 was selected from a group of other 12 fungi. From this group, Phlebia sp. MG-60 was the only one to exhibit the uncommon characteristic of degrade lignin and produce ethanol from cellulose [73]. This fungal strain has been evaluated in the production of ethanol from different feedstocks such as hardwood kraft pulp, waste newspaper, sugarcane bagasse, and hard wood [73-75]. The addition of basal media, organic compounds, and minerals to the culture media increased the ethanol yield and the delignification percentage [75]. Phlebia sp. MG-60 produced an ethanol yield between $30 \%$ and $70 \%$ depending of the type of biomass utilized [61]. The process duration is between 6 and 29 days and is associated with the type of biomass and the presence of pretreatment. The addition of alkali pretreatment generated a reduction in the process timespan from 21 days to $240 \mathrm{~h}$ [61]. On the other hand, fungi co-culture is an alternative to generated and integrated process for ethanol production. In this case, ethanol is produced by mixing two types of fungi to develop delignification, saccharification, and fermentation. Coprinus comatus and Trametes reesei were cultivated to produce ethanol from corn stover. In this case, coculture achieved greater delignification and cellulose conversion than monoculture [76].

Delignification using ligninolytic enzymes can be upgraded by improving the enzymatic catalysis using protein engineering. This area utilizes three types of approaches to modify ligninolytic enzymes: rational approaches, semi-rational approaches, and directed evolution [77]. Rational approaches are the molecular modification (site direct mutation) of the ligninolytic enzyme sequence using prior structural information as foundation for the 
specific sequence modification. Rational approaches have been used to improve the laccase ability to degrade nonphenolic substrates and to enhance the capacity to oxidize bulky phenolic molecules $[78,79]$. Semi-rational approaches employ saturation mutagenesis to modify hotspot residues in the enzymes. Saturation mutagenesis replaces the selected amino acids by all the codons that can generate the additional 19 amino acids [77]. This approach exhibited the production of enzymes with three- to eightfold higher catalytic efficiencies [80]. Directed molecular evolution is an approach that utilizes random mutation, gene recombination, and selection as fundaments. This molecular approach allows realizing the enzymatic design in absence of structural information. Direct molecular evolution has been used to improve catalytic activity and solvent tolerance [77].

The four delignification processes are compared in Table 2. In enzymatic and microbial process, the pros observed are: positive environmental impact, high delignification and detoxification, low sugar losses, and the possibility of develop a consolidate process. On the other hand, microbial and enzymatic have different cons. The enzymatic processes cons are: high costs, low commercial availability, and mediator necessity. Meanwhile, in microbial processes, the principal limitation is the process duration. Besides the limitations and assets, ligninolytic fungi and their enzymes represent an interesting option to the conventional chemical and physical processes used in biofuel production.

\section{Detoxification}

Some of the conventional biomass pretreatment technologies produce toxic compounds after treat biomass. These toxic compounds are classified in four groups: 1) furan derivatives, 2) pentose and hexose degradation, 3) weak acids, and 4) phenolic compounds from lignin [81]. These compounds affect the fermentative microorganisms and the cellulolytic enzymes, which generate an overall ethanol yield reduction [26].

The detoxification process employs chemical, physical, and biological strategies. Chemical and physical techniques utilize technologies such as filtration, anion exchange chromatography, and $\mathrm{NaOH}$ precipitation; these techniques are expensive, produce sugar losses, and do not remove all the inhibitors in the hydrolysates [12]. The biological detoxification (Table 3) process employs ligninolytic fungi or their enzymes to reduce the concentration of toxic compounds in feedstock hydrolysates [14]. The detoxification process is performed after or before the saccharification process and has a duration between 1 to $12 \mathrm{~h}[11,13,14,93]$. Detoxification after or before saccharification is a controversial point. Jurado et al. [93] recommended enzymatic detoxification after cellulose hydrolysis because enzymatic detoxification leads to a reduction in the saccharification process [93]. In contrast, Moreno et al. [26] suggested enzymatic detoxification before saccharification, because it enhances ethanol yield, reduces microbes lag phase, and generates an increment in substrate loading. The authors considered these positive factors more important than the reduction in glucose recovery [26].

From the four types of toxic compounds produced in biomass hydrolysates, phenolic compounds are the most degraded type by ligninolytic enzymes [14,93]. Phenolic compounds inhibited fermentation at concentration of $1 \mathrm{ppm}$ [98]. On the other hand, the other types of toxic compounds exhibit a variable behavior. These compound detoxification is affected by feedstock nature, enzyme characteristics, and pretreatment harshness [26]. Enzymatic detoxification has been applied in the reduction of toxicity after different pretreatments such as steam explosion, strong acids, organosolv, and hot liquid water. In addition, ligninolytic enzyme detoxification increase fermentation rates and ethanol yield [26]. As an example, in sugarcane bagasse, enzymatic detoxification generated an ethanol yield five times greater than ion exchange detoxification [14]. Lee et al. [96] improved the detoxification of rice straw hydrolysates by optimizing the temperature, enzyme concentration, and mediator compounds. The optimization increased the detoxification of phenolic compounds up to $92 \%$ by using HBT as mediator [96]. Ligninolytic enzyme detoxification is a future option for biofuel industries. However, this enzymatic option needs to improve their ability to degrade other types of toxic compounds from hydrolysates.

In recent years, enzymatic detoxification of furan derivatives has been evaluated. This type of detoxification is performed by aryl-alcohol oxidase (AAO) which is a less investigated group of ligninolytic enzymes. AAO have been assessed in the degradation of 5-hydroxymethylfurfural (HMF) and polyunsaturated alcohols [99-101]. Carro et al. [101] evaluated the transformation of HMF into 2,5furandicarboxylic acid (FDCA) by AAO catalysis. AAO

Table 2 Delignification technique comparison

\begin{tabular}{llllll}
\hline Delignification process & Delignification & Sugar losses & Process duration & Economic & Environmental impact \\
\hline Enzymatic & High & Low & 2 to $48 \mathrm{~h}$ & High costs & Positive \\
Fungal & High & Low & 6 to 45 days & Low costs & Positive \\
LMS & High & Low & 2 to $48 \mathrm{~h}$ & High costs & Depends of the mediator \\
IFF & Medium & Some & 1 to 12 weeks & Low costs & Positive \\
\hline
\end{tabular}


Table 3 Feedstock hydrolysates detoxification

\begin{tabular}{|c|c|c|c|c|c|c|}
\hline Feedstock & Microorganism & Enzyme & Pretreatment & Detoxification & Ethanol yield & Ref. \\
\hline & & Laccase & & $71 \%$ & 0.55 & \\
\hline \multirow[t]{2}{*}{ Wood } & \multirow[t]{2}{*}{ Trametes versicolor } & LiP & \multirow[t]{2}{*}{ Steam explosion, $205^{\circ} \mathrm{C}$ for 6 min. } & $53 \%$ & 0.40 & [9] \\
\hline & & Laccase+LiP & & $66 \%$ & 0.47 & \multirow{3}{*}{ [10] } \\
\hline \multirow{2}{*}{ Spruce chips } & \multirow{2}{*}{ Trametes reesei } & \multirow{2}{*}{ Laccase } & \multirow{2}{*}{$\mathrm{H}_{2} \mathrm{SO}_{4}(0.5 \%)$ Steam explosion, $222^{\circ} \mathrm{C}, 23$ bar $7 \mathrm{~min}$. } & $80 \%$ & 0.47 & \\
\hline & & & & $80 \%$ & 0.43 & \\
\hline Wheat straw & Trametes versicolor & Laccase & Hot liquid water at $180^{\circ} \mathrm{C}, 15 \mathrm{psi}, 30 \mathrm{~min}$. & $65 \%$ & - & [11] \\
\hline Sugarcane bagasse & Trametes versicolor & Laccase & Steam explosion, $215^{\circ} \mathrm{C}$ during $10 \mathrm{~min}$. & $80 \%$ & 0.43 & [13] \\
\hline Sugarcane bagasse & Cyathus stercoreus & Laccase & $\mathrm{HCl}(0.5-3.5 \% \mathrm{v} / \mathrm{v}), 140^{\circ} \mathrm{C}$ for $30 \mathrm{~min}$. & $77.5 \%$ & 0.374 & [14] \\
\hline Wheat straw & Coriolopsis rigida & Laccase & $\mathrm{H}_{2} \mathrm{SO}_{4}(1 \% \mathrm{w} / \mathrm{w}), 190^{\circ} \mathrm{C}, 12$ bars, $10 \mathrm{~min}$. & $75 \%$ & - & [93] \\
\hline Wheat straw & Trametes villosa & Laccase & Steam explosion, $220^{\circ} \mathrm{C}, 2.5 \mathrm{~min}$. & $88-92 \%$ & - & [26] \\
\hline Rice straw & Coltricia perennis & Laccase & $\mathrm{H}_{2} \mathrm{SO}_{4}(0.5 \% \mathrm{w} / \mathrm{w}), 121^{\circ} \mathrm{C}, 15 \mathrm{~min}$ & $37-76 \%$ & - & [94] \\
\hline Wheat straw & Trametes versicolor & Laccase & Ethanol organosolv process, $220^{\circ} \mathrm{C} 120 \mathrm{~min}$ & $20-90 \%$ & $0.374 \mathrm{~g} / \mathrm{g}$ & [95] \\
\hline \multirow{2}{*}{ Rice straw } & \multirow{2}{*}{ Yarrowia lipolytica } & Laccase & \multirow[t]{2}{*}{$\mathrm{H}_{2} \mathrm{SO}_{4}\left(0.5 \%\right.$, w/w 5 h, steam explosion $121^{\circ} \mathrm{C} 30 \mathrm{~min}$} & $52 \%$ & & \multirow{2}{*}{ [96] } \\
\hline & & LMS & & $92 \%$ & & \\
\hline Wheat straw & Pycnoporus cinnabarinus & Laccase & Steam explosion $200^{\circ} \mathrm{C}, 10 \mathrm{~min}$ & - & - & [97] \\
\hline
\end{tabular}

(Pleurotus eryngii) transformed efficiently HMF into 2,5-formylfurancarboxylic acid (FFCA); however, it was not capable of transforming directly from HMF into FDCA. To complete the catalysis of HMF, a fungal heme peroxygenase (Agrocybe aegerita) was added to the reaction. This enzyme transforms FFCA into FDCA using the $\mathrm{H}_{2} \mathrm{O}_{2}$ previously generated by AAO [101] Ferreira et al. [100] determined the ability of AAO to reduce polyunsaturated alcohols. They evaluated 12 different compounds; the best degradations were observed in benzyl alcohol, $\mathrm{m}$-fluorobenzyl alcohol, and p-fluorobenzyl alcohol. The enzyme has the ability to catalyze 'nonactivated' alcohols which is an important factor for future detoxification procedures [100]. Other enzymatic process to transform furfurals have been studied; however, these processes utilize non-ligninolytic enzymes from different types of bacteria. In the future, furfural detoxification using ligninolytic enzymes need to be tested in biomass hydrolysates to have a more accurate vision of their real efficiency and applicability.

\section{Conclusions}

Ligninolytic fungi and their enzymes exhibited several biophysics and biochemical characteristics that have been applied in the delignification and detoxification of biofuel feedstocks. Ligninolytic processes (enzymatic and fungal) produce ethanol yield, glucose conversion, and delignification and detoxification percentages similar or superior than conventional detoxification and delignification methodologies. Nevertheless, ligninolytic processes have low cellulose modification, the presence of mediators, and long duration process (fungal processes).
The transformation of ligninolytic enzymes as viable option for biofuel industry requires the improvements in the process duration, cost reduction, and more specialized mediators.

\section{Competing interests}

The authors of this manuscript do not have any financial competing interest to declare.

\section{Authors' contributions}

JP manuscript drafting and writing. SC was responsible of final manuscript approval. Both authors read and approved the final manuscript.

\section{Acknowledgements}

The Colombian government and the Fulbright organization are acknowledged for the financial support via the granting of FULBRIGHTCOLCIENCIAS for the Ph.D. studies of Jersson Plácido in the USA.

Received: 16 March 2015 Accepted: 16 April 2015

Published online: 19 May 2015

\section{References}

1. Sissine F, Energy Independence and Security Act of 2007: a summary of major provisions. 2007; 2011.

2. Dias AA, Freitas GS, Marques GSM, Sampaio A, Fraga IS, Rodrigues MAM, Evtuguin DV, Bezerra RMF (2010) Enzymatic saccharification of biologically pre-treated wheat straw with white-rot fungi. Bioresour Technol 101:6045-6050. doi:10.1016/j.biortech.2010.02.110

3. Salvachúa D, Prieto A, López-Abelairas M, Lu-Chau T, Martínez ÁT, Martínez MJ (2011) Fungal pretreatment: an alternative in second-generation ethanol from wheat straw. Bioresour Technol 102:7500-7506. doi:10.1016/j.biortech.2011.05.027

4. Wan C, Li Y (2011) Effectiveness of microbial pretreatment by Ceriporiopsis subvermispora on different biomass feedstocks. Bioresour Technol 102:7507-7512. doi:10.1016/j.biortech.2011.05.026

5. Nigam P, Gupta N, Anthwal A. Pre-treatment of agro-industrial residues. In: Nigam P and Pandey A. Biotechnology for Agro-Industrial Residues Utilisation, Springer Netherlands; 2009, p. 13-33.

6. Li L, Li X, Tang W, Zhao J, Qu Y (2008) Screening of a fungus capable of powerful and selective delignification on wheat straw. Lett Appl Microbiol 47:415-420. doi:10.1111/j.1472-765X.2008.02447.x 
7. Wan C, Li Y (2010) Microbial delignification of corn stover by Ceriporiopsis subvermispora for improving cellulose digestibility. Enzyme Microb Technol 47:31-36. doi:10.1016/j.enzmictec.2010.04.001

8. Lu C, Wang H, Luo Y, Guo L (2010) An efficient system for predelignification of gramineous biofuel feedstock in vitro: application of a laccase from Pycnoporus sanguineus H275. Process Biochemistry 45:1141-1147. doi:10.1016/j.procbio.2010.04.010

9. Jönsson LJ, Palmqvist E, Nilvebrant N- and Hahn-Hägerdal B (1998) Detoxification of wood hydrolysates with laccase and peroxidase from the white-rot fungus Trametes versicolor. Appl Microbiol Biotechnol 49:691-697. doi:10.1007/s002530051233

10. Larsson S, Reimann A, Nilvebrant N, Jönsson L (1999) Comparison of different methods for the detoxification of lignocellulose hydrolyzates of spruce. Appl Biochem Biotechnol 77:91-103. doi:10.1385/ABAB:77:1-3:91

11. Kolb M, Sieber $V$, Amann M, Faulstich M, Schieder D (2012) Removal of monomer delignification products by laccase from Trametes versicolor. Bioresour Technol 104:298-304. doi:10.1016/j.biortech.2011.11.080

12. Palmqvist E and Hahn-Hägerdal B (2000) Fermentation of lignocellulosic hydrolysates. I: inhibition and detoxification. Bioresour Technol 74:17-24. doi:10.1016/S0960-8524(99)00160-1.

13. Martín C, Galbe M, Wahlbom CF, Hahn-Hägerdal B and Jönsson $\sqcup$ (2002) Ethanol production from enzymatic hydrolysates of sugarcane bagasse using recombinant xylose-utilising Saccharomyces cerevisiae. Enzyme Microb Technol 31:274-282. doi:10.1016/S0141-0229(02)00112-6.

14. Chandel AK, Kapoor RK, Singh A, Kuhad RC (2007) Detoxification of sugarcane bagasse hydrolysate improves ethanol production by Candida shehatae NCIM 3501. Bioresour Technol 98:1947-1950. doi:10.1016/ j.biortech.2006.07.047

15. Minussi RC, Pastore GM, Durán N (2007) Laccase induction in fungi and laccase/N-OH mediator systems applied in paper mill effluent. Bioresour Technol 98:158-164

16. Matera I, Gullotto A, Tilli S, Ferraroni M, Scozzafava A, Briganti F (2008) Crystal structure of the blue multicopper oxidase from the white-rot fungus Trametes trogii complexed with p-toluate. Inorg Chim Acta 361:4129-4137. doi:10.1016/j.ica.2008.03.091

17. Zouari-Mechichi H, Mechichi T, Dhouib A, Sayadi S, Martínez AT, Martínez MJ (2006) Laccase purification and characterization from Trametes trogii isolated in Tunisia: decolorization of textile dyes by the purified enzyme. Enzyme Microb Technol 39:141-148. doi:10.1016/j.enzmictec.2005.11.027

18. Corvini P, Schäffer A, Schlosser D (2006) Microbial degradation of nonylphenol and other alkylphenols - our evolving view. Appl Microbiol Biotechnol 72:223-243. doi:10.1007/s00253-006-0476-5

19. Babot ED, Rico A, Rencoret J, Kalum L, Lund H, Romero J, del Río JC, Martínez ÁT, Gutiérrez A (2011) Towards industrially-feasible delignification and pitch removal by treating paper pulp with Myceliophthora thermophila laccase and a phenolic mediator. Bioresour Technol 102:6717-6722. doi:10.1016/j.biortech.2011.03.100

20. Sergio R (2006) Laccases: blue enzymes for green chemistry. Trends Biotechnol 24:219-226

21. Couto S, Toca-Herrera J (2006) Lacasses in the textile industry. Biotechnol Mol Biol Rev 1:115-120

22. Kokol V, Doliška A, Eichlerová I, Baldrian P, Nerud F (2007) Decolorization of textile dyes by whole cultures of Ischnoderma resinosum and by purified laccase and Mn-peroxidase. Enzyme Microb Technol 40:1673-1677. doi:10.1016/j.enzmictec.2006.08.015

23. Michniewicz A, Ledakowicz S, Ullrich R, Hofrichter M (2008) Kinetics of the enzymatic decolorization of textile dyes by laccase from Cerrena unicolor. Dyes and Pigments 77:295-302. doi:10.1016/j.dyepig.2007.05.015

24. Shanmugam S, Palvannan T, Sathish Kumar T, Michael A (2005) Biological decolourization of textile and paper effluents by Pleurotus florida and Agaricus bisporus (white-rot Basidiomycetes). World Journal of Microbiology and Biotechnology 21:1149-1151. doi:10.1007/s11274-005-0298-0

25. Chanagá Vera X, Plácido Escobar J, Marín Montoya M, Pérez Y, del Socorro M (2012) Native fungi with industrial dye degrading potential in the Aburrá Valley, Colombia. Revista Facultad Nacional de Agronomía, Medellín 65:6811-6821

26. Moreno AD, Ibarra D, Fernández JL, Ballesteros M (2012) Different laccase detoxification strategies for ethanol production from lignocellulosic biomass by the thermotolerant yeast Kluyveromyces marxianus CECT 10875. Bioresour Technol 106:101-109. doi:10.1016/ j.biortech.2011.11.108
27. Plácido J, Imam T, Capareda S (2013) Evaluation of ligninolytic enzymes, ultrasonication and liquid hot water as pretreatments for bioethanol production from cotton gin trash. Bioresour Technol 139:203-208. doi:10.1016/j.biortech.2013.04.012

28. Plácido J, Capareda S (2014) Analysis of alkali ultrasonication pretreatment in bioethanol production from cotton gin trash using FT-IR spectroscopy and principal component analysis. Bioresources and Bioprocessing 1:1-9

29. Ferraroni M, Myasoedova N, Schmatchenko V, Leontievsky A, Golovleva L, Scozzafava A, Briganti F (2007) Crystal structure of a blue laccase from Lentinus tigrinus: evidences for intermediates in the molecular oxygen reductive splitting by multicopper oxidases. BMC Structural Biology 7:60

30. Bertrand T, Jolivalt C, Briozzo P, Caminade E, Joly N, Madzak C, Mougin C (2002) Crystal structure of a four-copper laccase complexed with an Arylamine: insights into substrate recognition and correlation with kinetics. Biochemistry (N Y ) 41:7325-7333. doi:10.1021/bi0201318

31. Hakulinen N, Kiiskinen L, Kruus K, Saloheimo M, Paananen A, Koivula A, Rouvinen J (2002) Crystal structure of a laccase from Melanocarpus albomyces with an intact trinuclear copper site. Nat Struct Mol Biol 9:601-605

32. Dias A, Sampaio A, Bezerra R. Environmental applications of fungal and plant systems: decolourisation of textile wastewater and related dyestuffs. In: Singh S and Tripathi R. Environmental Bioremediation Technologies, Springer Berlin Heidelberg; 2007, p. 445-463.

33. Holwerda RA, Wherland S, Gray HB (1976) Electron transfer reactions of copper proteins. Annu Rev Biophys Bioeng 5:363-396. doi:10.1146/annurev.bb.05.060176.002051

34. Alcalde M. Laccases: biological functions, molecular structure and industrial applications. In: Polaina J and MacCabe AP. Industrial Enzymes, Springer Netherlands; 2007, p. 461-476.

35. Garavaglia S, Teresa Cambria M, Miglio M, Ragusa S, lacobazzi V, Palmieri F, D'Ambrosio C, Scaloni A, Rizzi M (2004) The structure of Rigidoporus lignosus laccase containing a full complement of copper ions, reveals an asymmetrical arrangement for the T3 copper pair. J Mol Biol 342:1519-1531. doi:10.1016/j.jmb.2004.07.100

36. Piontek K, Glumoff T, Winterhalter K (1993) Low pH crystal structure of glycosylated lignin peroxidase from Phanerochaete chrysosporium at $2.5 \AA$ resolution. FEBS Lett 315:119-124. doi:10.1016/0014-5793(93)81146-Q

37. Sundaramoorthy M, Kishi K, Gold MH, Poulos TL (1994) The crystal structure of manganese peroxidase from Phanerochaete chrysosporium at 2.06-A resolution. Journal of Biological Chemistry 269:32759-32767

38. Angel TM (2002) Molecular biology and structure-function of lignindegrading heme peroxidases. Enzyme Microb Technol 30:425-444. doi:10.1016/S0141-0229(01)00521-X

39. Choinowski T, Blodig W, Winterhalter KH, Piontek K (1999) The crystal structure of lignin peroxidase at $1.70 \AA$ resolution reveals a hydroxy group on the $C \beta$ of tryptophan 171: a novel radical site formed during the redox cycle. J Mol Biol 286:809-827. doi:10.1006/jmbi.1998.2507

40. Khindaria A, Yamazaki I, Aust SD (1996) Stabilization of the veratryl alcohol cation radical by lignin peroxidase. Biochemistry (N Y) 35:6418-6424. doi:10.1021/bi9601666

41. Hammel KE, Cullen D (2008) Role of fungal peroxidases in biological ligninolysis. Curr Opin Plant Biol 11:349-355. doi:10.1016/j.pbi.2008.02.003

42. Martin H, (2002) Review: lignin conversion by manganese peroxidase (MnP). Enzyme Microb Technol 30:454-466. doi:10.1016/S0141-0229(01)00528-2.

43. Polak J, Jarosz-Wilkolazka A (2012) Fungal laccases as green catalysts for dye synthesis. Process Biochemistry 47:1295-1307. doi:10.1016/j.procbio.2012.05.006

44. Hoopes JT, Dean JFD (2004) Ferroxidase activity in a laccase-like multicopper oxidase from Liriodendron tulipifera. Plant Physiology and Biochemistry 42:27-33. doi:10.1016/j.plaphy.2003.10.011

45. Bugg TD, Ahmad M, Hardiman EM, Singh R (2011) The emerging role for bacteria in lignin degradation and bio-product formation. Curr Opin Biotechnol 22:394-400. doi:10.1016/j.copbio.2010.10.009

46. Ramachandra M, Crawford DL, Hertel G (1988) Characterization of an extracellular lignin peroxidase of the lignocellulolytic actinomycete Streptomyces viridosporus. Appl Environ Microbiol 54:3057-3063

47. Adav SS, Ng CS, Arulmani M, Sze SK (2010) Quantitative iTRAQ secretome analysis of cellulolytic thermobifida fusca. Journal of Proteome Research 9:3016-3024

48. Gupta N, Farinas ET (2010) Directed evolution of CotA laccase for increased substrate specificity using Bacillus subtilis spores. Protein Engineering, Design and Selection 23:679-682 
49. [49] Faure D, Bouillant M- and Bally R (1995) Comparative study of substrates and inhibitors of Azospirillum lipoferum and Pyricularia oryzae laccases. Appl Environ Microbiol 61:1144-1146

50. Miyazaki K (2005) A hyperthermophilic laccase from Thermus thermophilus HB27. Extremophiles 9:415-425

51. Arias ME, Arenas M, Rodríguez J, Soliveri J, Ball AS, Hernández M (2003) Kraft pulp biobleaching and mediated oxidation of a nonphenolic substrate by laccase from Streptomyces cyaneus CECT 3335. Appl Environ Microbiol 69:1953-1958

52. Dwivedi UN, Singh P, Pandey VP, Kumar A (2011) Structure-function relationship among bacterial, fungal and plant laccases. J Molec Catal B 68:117-128. doi:10.1016/j.molcatb.2010.11.002

53. Hattori M, Tsuchihara K, Noda H, Konishi H, Tamura Y, Shinoda T, Nakamura M, Hasegawa T (2010) Molecular characterization and expression of laccase genes in the salivary glands of the green rice leafhopper, Nephotettix cincticeps (Hemiptera: Cicadellidae). Insect Biochem Mol Biol 40:331-338. doi:10.1016/j.ibmb.2010.02.009

54. Dittmer NT, Suderman RJ, Jiang H, Zhu Y, Gorman MJ, Kramer KJ, Kanost MR (2004) Characterization of cDNAs encoding putative laccase-like multicopper oxidases and developmental expression in the tobacco hornworm, Manduca sexta, and the malaria mosquito, Anopheles gambiae. Insect Biochem Mol Biol 34:29-41

55. Coy MR, Salem TZ, Denton JS, Kovaleva ES, Liu Z, Barber DS, Campbell JH, Davis DC, Buchman GW, Boucias DG, Scharf ME (2010) Phenol-oxidizing laccases from the termite gut. Insect Biochem Mol Biol 40:723-732. doi:10.1016/j.ibmb.2010.07.004

56. Arakane Y, Muthukrishnan S, Beeman RW, Kanost MR, Kramer KJ (2005) Laccase 2 is the phenoloxidase gene required for beetle cuticle tanning. Proc Natl Acad Sci U S A 102:11337-11342

57. dos Santos AB, Cervantes FJ, van Lier JB (2007) Review paper on current technologies for decolourisation of textile wastewaters: perspectives for anaerobic biotechnology. Bioresour Technol 98:2369-2385. doi:10.1016/j.biortech.2006.11.013

58. Martínez ÁT, Ruiz-Dueñas FJ, Martínez MJ, del Río JC, Gutiérrez A (2009) Enzymatic delignification of plant cell wall: from nature to mill. Curr Opin Biotechnol 20:348-357. doi:10.1016/j.copbio.2009.05.002

59. Vivekanand V, Dwivedi P, Sharma A, Sabharwal N, Singh R (2008) Enhanced delignification of mixed wood pulp by Aspergillus fumigatus laccase mediator system. World Journal of Microbiology and Biotechnology 24:2799-2804. doi:10.1007/s11274-008-9809-0

60. Martín-Sampedro R, Eugenio ME, Carbajo JM, Villar JC (2011) Combination of steam explosion and laccase-mediator treatments prior to Eucalyptus globulus kraft pulping. Bioresour Technol 102:7183-7189. doi:10.1016/j.biortech.2011.04.053

61. Khuong LD, Kondo R, De Leon R, Kim Anh T, Shimizu K and Kamei I (2014) Bioethanol production from alkaline-pretreated sugarcane bagasse by consolidated bioprocessing using Phlebia sp. MG-60. Int Biodeterior Biodegrad 88:62-68. doi:http://dx.doi.org/10.1016/j.ibiod.2013.12.008.

62. López-Abelairas M, Pallín MÁ, Salvachúa D, Lú-Chau T, Martínez M, Lema J (2013) Optimisation of the biological pretreatment of wheat straw with white-rot fungi for ethanol production. Bioprocess and biosystems engineering 36:1251-1260

63. Mattinen M, Maijala P, Nousiainen P, Smeds A, Kontro J, Sipilä J, Tamminen T, Willför S, Viikari L (2011) Oxidation of lignans and lignin model compounds by laccase in aqueous solvent systems. J Molec Catal B 72:122-129. doi:10.1016/j.molcatb.2011.05.009

64. Costa SM, Goncalves AR, Esposito E. Ceriporiopsis Subvermispota used in delignification of sugarcane bagasse prior to soda/anthraquinone pulping. In: Davison BH, Evans BR, Finkelstein M and McMillan JD. Twenty-Sixth Symposium on Biotechnology for Fuels and Chemicals, Humana Press; 2005, p. 695-706.

65. Archibald FS, Bourbonnais R, Jurasek L, Paice MG and Reid ID (1997) Kraft pulp bleaching and delignification by Trametes versicolor. J Biotechnol 53:215-236. doi:10.1016/S0168-1656(97)01675-1.

66. Wang F, Xie H, Chen W, Wang E, Du F, Song A (2013) Biological pretreatment of corn stover with ligninolytic enzyme for high efficient enzymatic hydrolysis. Bioresour Technol 144:572-578

67. Asgher M, Ahmad Z and lqbal HMN (2013) Alkali and enzymatic delignification of sugarcane bagasse to expose cellulose polymers for saccharification and bio-ethanol production. Industrial Crops and Products 44:488-495. doi:http://dx.doi.org/10.1016/j.indcrop.2012.10.005.
68. Fillat U, Blanca Roncero M (2009) Effect of process parameters in laccasemediator system delignification of flax pulp: Part I. Pulp properties Chem Eng J 152:322-329. doi:10.1016/j.cej.2009.05.036

69. Camarero S, García O, Vidal T, Colom J, del Río JC, Gutiérrez A, Gras JM Monje R, Martínez MJ and Martínez ÁT (2004) Efficient bleaching of nonwood high-quality paper pulp using laccase-mediator system. Enzyme Microb Technol 35:113-120. doi:10.1016/j.enzmictec.2003.10.019.

70. Chen Q, Marshall MN, Geib SM, Tien M, Richard TL (2012) Effects of laccase on lignin depolymerization and enzymatic hydrolysis of ensiled corn stover. Bioresour Technol 117:186-192. doi:10.1016/j.biortech.2012.04.085

71. Qiu W, Chen H (2012) Enhanced the enzymatic hydrolysis efficiency of wheat straw after combined steam explosion and laccase pretreatment. Bioresour Technol 118:8-12. doi:10.1016/j.biortech.2012.05.033

72. Gutiérrez A, Rencoret J, Cadena EM, Rico A, Barth D, del Río JC and Martínez ÁT (2012) Demonstration of laccase-based removal of lignin from wood and non-wood plant feedstocks. Bioresour Technol 119:114-122. doi:http://dx.doi.org/10.1016/j.biortech.2012.05.112.

73. Kamei I, Hirota Y, Mori T, Hirai H, Meguro S and Kondo R (2012) Direct ethanol production from cellulosic materials by the hypersaline-tolerant white-rot fungus Phlebia sp. MG-60. Bioresour Technol 112:137-142. doi:http://dx.doi.org/10.1016/j.biortech.2012.02.109.

74. Kamei I, Hirota Y and Meguro S (2012) Integrated delignification and simultaneous saccharification and fermentation of hard wood by a whiterot fungus, Phlebia sp. MG-60. Bioresour Technol 126:137-141. doi:http://dx.doi.org/10.1016/j.biortech.2012.09.007.

75. Khuong LD, Kondo R, Leon RD, Anh TK, Meguro S, Shimizu K and Kamei I (2014) Effect of chemical factors on integrated fungal fermentation of sugarcane bagasse for ethanol production by a white-rot fungus, Phlebia sp. MG-60. Bioresour Technol 167:33-40. doi:http://dx.doi.org/10.1016/ j.biortech.2014.05.064.

76. Ma K and Ruan Z (2015) Production of a lignocellulolytic enzyme system for simultaneous bio-delignification and saccharification of corn stover employing co-culture of fungi. Bioresour Technol 175:586-593. doi:http://dx.doi.org/10.1016/j.biortech.2014.10.161.

77. Mate DM and Alcalde M (2015) Laccase engineering: from rational design to directed evolution. Biotechnol Adv 33:25-40. doi:http://dx.doi.org.scopeesprx.elsevier.com/10.1016/j.biotechadv.2014.12.007.

78. Madzak C, Mimmi MC, Caminade E, Brault A, Baumberger S, Briozzo P, Mougin C, Jolivalt C (2006) Shifting the optimal pH of activity for a laccase from the fungus Trametes versicolor by structure-based mutagenesis. Protein Engineering, Design and Selection 19:77-84

79. Galli C, Gentili P, Jolivalt C, Madzak C, Vadalà R (2011) How is the reactivity of laccase affected by single-point mutations? Engineering laccase for improved activity towards sterically demanding substrates. Appl Microbiol Biotechnol 91:123-131

80. Andberg M, Hakulinen N, Auer S, Saloheimo M, Koivula A, Rouvinen J, Kruus K (2009) Essential role of the C-terminus in Melanocarpus albomyces laccase for enzyme production, catalytic properties and structure. FEBS Journal 276:6285-6300

81. Annunziatini C, Baiocco P, Gerini MF, Lanzalunga O, Sjögren B (2005) Aryl substituted $\mathrm{N}$-hydroxyphthalimides as mediators in the laccase-catalysed oxidation of lignin model compounds and delignification of wood pulp. J Molec Catal B 32:89-96. doi:10.1016/j.molcatb.2004.11.002

82. Oudia A, Queiroz J, Simões R (2008) The influence of operating parameters on the biodelignification of Eucalyptus globulus kraft pulps in a laccasevioluric acid system. Appl Biochem Biotechnol 149:23-32. doi:10.1007/s12010-008-8138-y

83. Mukhopadhyay M, Kuila A, Tuli DK, Banerjee R (2011) Enzymatic depolymerization of Ricinus communis, a potential lignocellulosic for improved saccharification. Biomass Bioenergy 35:3584-3591. doi:10.1016/j.biombioe.2011.05.013

84. Ibarra D, Romero J, Martínez MJ, Martínez AT, Camarero S (2006) Exploring the enzymatic parameters for optimal delignification of eucalypt pulp by laccase-mediator. Enzyme Microb Technol 39:1319-1327. doi:10.1016/j.enzmictec.2006.03.019

85. Pinto PA, Dias AA, Fraga I, Marques G, Rodrigues MAM, Colaço J, Sampaio A Bezerra RMF (2012) Influence of ligninolytic enzymes on straw saccharification during fungal pretreatment. Bioresour Technol 111:261-267. doi:10.1016/j.biortech.2012.02.068

86. Kondo R, De Leon R, Anh TK, Meguro S, Shimizu K, Kamei I (2014) Effect of chemical factors on integrated fungal fermentation of sugarcane bagasse 
for ethanol production by a white-rot fungus, Phlebia sp. MG-60. Bioresour Technol 167:33-40

87. Dong XQ, Yang JS, Zhu N, Wang ET, Yuan HL (2013) Sugarcane bagasse degradation and characterization of three white-rot fungi. Bioresour Technol 131:443-451

88. Ishola MM, Isroi and Taherzadeh MJ (2014) Effect of fungal and phosphoric acid pretreatment on ethanol production from oil palm empty fruit bunches (OPEFB). Bioresour Technol 165:9-12. doi:http://dx.doi.org/10.1016/ j.biortech.2014.02.053.

89. Suhara H, Kodama S, Kamei I, Maekawa N, Meguro S (2012) Screening of selective lignin-degrading basidiomycetes and biological pretreatment for enzymatic hydrolysis of bamboo culms. Int Biodeterior Biodegrad 75:176-180

90. Wang W, Yuan T, Cui B, Dai Y (2012) Pretreatment of Populus tomentosa with Trametes velutina supplemented with inorganic salts enhances enzymatic hydrolysis for ethanol production. Biotechnol Lett 34:2241-2246

91. Deswal D, Gupta R, Nandal P and Kuhad RC (2014) Fungal pretreatment improves amenability of lignocellulosic material for its saccharification to sugars. Carbohydr Polym 99:264-269. doi:http://dx.doi.org/10.1016/ j.carbpol.2013.08.045

92. Song L, Ma F, Zeng Y, Zhang X and Yu H (2013) The promoting effects of manganese on biological pretreatment with Irpex lacteus and enzymatic hydrolysis of corn stover. Bioresour Technol 135:89-92. doi:http://dx.doi.org/ 10.1016/j.biortech.2012.09.004.

93. Jurado M, Prieto A, Martínez-Alcalá Á, Martínez ÁT, Martínez MJ (2009) Laccase detoxification of steam-exploded wheat straw for second generation bioethanol. Bioresour Technol 100:6378-6384. doi:10.1016/j.biortech.2009.07.049

94. Kalyani D, Dhiman SS, Kim H, Jeya M, Kim I and Lee J (2012 Characterization of a novel laccase from the isolated Coltricia perennis and its application to detoxification of biomass. Process Biochemistry 47:671-678. doi:http://dx.doi.org/10.1016/j.procbio.2012.01.013.

95. Ludwig D, Amann M, Hirth T, Rupp S and Zibek S (2013) Development and optimization of single and combined detoxification processes to improve the fermentability of lignocellulose hydrolyzates. Bioresour Technol 133:455-461. doi:http://dx.doi.org/10.1016/j.biortech.2013.01.053.

96. Lee K, Kalyani D, Tiwari MK, Kim T, Dhiman SS, Lee J and Kim I (2012) Enhanced enzymatic hydrolysis of rice straw by removal of phenolic compounds using a novel laccase from yeast Yarrowia lipolytica. Bioresour Technol 123:636-645. doi:http://dx.doi.org/10.1016/j.biortech.2012.07.066.

97. Oliva-Taravilla A, Moreno AD, Demuez M, Ibarra D, Tomás-Pejó E, GonzálezFernández C and Ballesteros M (2015) Unraveling the effects of laccase treatment on enzymatic hydrolysis of steam-exploded wheat straw. Bioresour Technol 175:209-215. doi:http://dx.doi.org/10.1016/ j.biortech.2014.10.086.

98. Delgenes JP, Moletta R and Navarro JM (1996) Effects of lignocellulose degradation products on ethanol fermentations of glucose and xylose by Saccharomyces cerevisiae, Zymomonas mobilis, Pichia stipitis, and Candida shehatae. Enzyme Microb Technol 19:220-225. doi:10.1016/0141-0229(95)00237-5.

99. Dijkman WP, Groothuis DE, Fraaije MW (2014) Enzyme-catalyzed oxidation of 5-hydroxymethylfurfural to furan-2,5-dicarboxylic acid. Angewandte Chemie International Edition 53:6515-6518. doi:10.1002/anie.201402904

100. Ferreira P, Medina M, Guillén F, Martinez M, Van Berkel W, Martinez A (2005) Spectral and catalytic properties of aryl-alcohol oxidase, a fungal flavoenzyme acting on polyunsaturated alcohols. Biochem J 389:731-738

101. Carro J, Ferreira P, Rodríguez L, Prieto A, Serrano A, Balcells B, Ardá A, Jiménez-Barbero J, Gutiérrez A, Ullrich R, Hofrichter M, Martínez AT (2015) 5-hydroxymethylfurfural conversion by fungal aryl-alcohol oxidase and unspecific peroxygenase. FEBS Journal:n/a-n/a. doi:10.1111/febs.13177

\section{Submit your manuscript to a SpringerOpen ${ }^{\circ}$ journal and benefit from:}

- Convenient online submission

- Rigorous peer review

- Immediate publication on acceptance

- Open access: articles freely available online

- High visibility within the field

- Retaining the copyright to your article

Submit your next manuscript at $>$ springeropen.com 